\title{
Application of terminal RFLP analysis to characterize oral bacterial flora in saliva of healthy subjects and patients with periodontitis
}

\author{
Mitsuo Sakamoto, ${ }^{1}$ Yasuo Takeuchi, ${ }^{2}$ Makoto Umeda, ${ }^{2}$ Isao Ishikawa ${ }^{2}$ and \\ Yoshimi Benno ${ }^{1}$
}

Correspondence

Mitsuo Sakamoto

sakamoto@jcm.riken.go.jp

Received 11 June 2002

Accepted 23 August 2002

\author{
1 Japan Collection of Microorganisms, RIKEN, Wako, Saitama 351-0198 Japan \\ ${ }^{2}$ Division of Periodontology, Department of Hard Tissue Engineering, Graduate School, Tokyo Medical \\ and Dental University, Bunkyo-ku, Tokyo 113-8549, Japan
}

\section{INTRODUCTION}

A large number and variety of bacteria exist in the human oral cavity. However, analysis of these bacterial communities has been limited by conventional culture-dependent methods; thus, many oral bacteria remain uncultured and uncharacterized. Consequently, studies of causal microorganisms of oral diseases including periodontal disease are, in general, restricted to cultivable species.

Recently, a phylogenetic approach based on 16S rRNA genes (rDNA) has been applied to investigate the diversity of cultivable and non-cultivable species in the human oral cavity without cultivation (Choi et al., 1994, 1996; Dymock et al., 1996; Kroes et al., 1999; Paster et al., 2001; Sakamoto

Abbreviations: T-RF, terminal restriction fragment; T-RFLP, terminal restriction fragment length polymorphism.

T-RFLP patterns of $16 \mathrm{~S}$ rDNAs are available as supplementary data in JMM Online (http://jmm.sgmjournals.org). et al., 2000; Spratt et al., 1999). The 16S rDNA clone library method can provide direct sequence information. Paster et al. (2001) demonstrated that the predominant subgingival microbial community consisted of 347 species or phylotypes, based on analysis of 2522 16S rRNA clones. However, analysis of individual $16 \mathrm{~S}$ rDNA clones is an expensive and extremely inefficient approach for comparison of a multitude of bacterial communities.

Terminal restriction fragment-length polymorphism ( $\mathrm{T}$ RFLP) is a new molecular approach that allows the assessment of a diversity of complex bacterial communities and rapid comparison of the community structure and diversity of different ecosystems (Liu et al., 1997). This technique has been used for assessing the diversity and structure of complex bacterial communities in various environments (Clement et al., 1998; Dunbar et al., 2000; Gonzàlez et al., 2000; Hiraishi et al., 2000; Kaplan et al., 2001; Leser et al., 2000; Lukow et al., 2000; Moeseneder et al., 1999) and evaluated in separate review articles (Kitts, 2001; Marsh, 1999). In addition, the T- 
RFLP analysis program (TAP) has been developed and published on the worldwide web (http://rdp.cme.msu.edu/ $\mathrm{html} /$ analyses.html) (Marsh et al., 2000). Understanding the bacterial flora in the human oral cavity is essential for a full description of the causative bacteria of periodontal diseases. The T-RFLP method allows the recognition of diverse oral bacterial flora and rapid comparison of the community structure among patients with periodontitis. Hence, this method may be also useful for the rapid diagnosis of periodontal disease, although it has not yet been applied for the diagnosis of such diseases.

In the study of the oral bacterial community, saliva seems to be the most suitable sample as it is considered to contain a variety of bacteria from different oral sites (e.g. tongue, subgingival plaque, supragingival plaque), in addition to the ease of sampling. In a $16 \mathrm{~S}$ rDNA clone library analysis of human saliva, we found the oral bacterial flora in a healthy subject to be different from that in periodontitis patients (Sakamoto et al., 2000). This finding indicated that the use of saliva as well as subgingival plaque in the analysis of the oral bacterial community is effective. In addition, periodontopathic bacteria such as Actinobacillus actinomycetemcomitans, Tannerella forsythensis (formerly Bacteroides forsythus) (Sakamoto et al., 2002), Porphyromonas gingivalis, Treponema denticola and Treponema socranskii were more frequently detected in saliva than in subgingival plaque samples by the real-time PCR (Sakamoto et al., 2001). These results confirmed those of a previous study (Umeda et al., 1998). The levels of target bacteria may vary considerably from pocket to pocket and a pooled sample from sites of periodontitis may occasionally be missing organisms. It may also be that whole saliva simply contains higher concentrations of target bacteria than a subgingival plaque sample. This finding sug- gested that saliva is equal to or better than subgingival plaque for detecting and quantifying periodontopathic bacteria in the oral cavity.

In the present study, we used T-RFLP analysis to characterize and compare oral bacterial flora present in saliva samples of healthy subjects and patients with periodontitis. As the aim of this study was to apply a novel technique to evaluate the diversity of cultivable and non-cultivable species in the human oral cavity, the cultivation-dependent approach was not used. To our knowledge, this is the first report on characterization of oral bacterial flora based on T-RFLP patterns.

\section{METHODS}

Bacterial strains and DNA extraction. The bacterial strains used in the present study are listed in Table 1 . All bacteria were grown under appropriate culture conditions. Bacterial DNA was prepared as described previously (Sakamoto et al., 1999).

\begin{abstract}
Subject populations. Patients with periodontitis were divided into three groups based on the amount of probing depth (PD). (i) Group 1 (early periodontitis; P2, P3, P8, P10, P14 and P18) was defined as follows: teeth with $\mathrm{PD} \geqslant 4 \mathrm{~mm}$ were less than $50 \%$ of non-missing teeth. (ii) Group 2 (moderate periodontitis; P4, P5, P7, P9, P11 and P15) was defined as follows: teeth with $\mathrm{PD} \geqslant 4 \mathrm{~mm}$ were $50 \%$ or more of non-missing teeth and teeth with $\mathrm{PD} \geqslant 6 \mathrm{~mm}$ were less than $30 \%$ of non-missing teeth. (iii) Group 3 (severe periodontitis; P1, P6, P12, P13, P16 and P17) was defined as follows: teeth with PD $\geqslant 4 \mathrm{~mm}$ were $50 \%$ or more of non-missing teeth and teeth with $\mathrm{PD} \geqslant 6 \mathrm{~mm}$ were $30 \%$ or more of non-missing teeth.
\end{abstract}

Sample collection and DNA extraction. Saliva samples were collected in sterile plastic tubes from the above 18 patients with periodontitis [mean age \pm standard deviation $(\mathrm{SD})=45 \cdot 8 \pm 14.5$ years] and from 18 periodontally healthy subjects $(33.4 \pm 11.7$ years $)$. The $0.5 \mathrm{ml}$

Table 1. Predicted and observed T-RF lengths (bp) for organisms used in the present study after digestion with $\mathrm{Hhal}$ and $\mathrm{Mspl}$

\begin{tabular}{|c|c|c|c|c|}
\hline \multirow[t]{2}{*}{ Organism } & \multicolumn{2}{|c|}{ HhaI } & \multicolumn{2}{|c|}{$M s p I^{*}$} \\
\hline & Predicted & Observed & Predicted & Observed \\
\hline Actinobacillus actinomycetemcomitans JCM 2434 & 364 & 362 & 309 & 305 \\
\hline Campylobacter gracilis JCM $8538^{\mathrm{T}}$ & 98 & 95 & 470 & 467 \\
\hline Campylobacter rectus JCM $6301^{\mathrm{T}}$ & 96 & 93 & 468 & 465 \\
\hline Capnocytophaga gingivalis DSM $3290^{\mathrm{T}}$ & 90 & 86 & 85 & 82 \\
\hline Eikenella corrodens DSM $8340^{\mathrm{T}}$ & 575 & 573 & 89 & 86 \\
\hline Fusobacterium nucleatum JCM $8532^{\mathrm{T}}$ & 212 & 211 & 282 & $292(283)$ \\
\hline Porphyromonas gingivalis JCM 8525 & 102 & 98 & 97 & 95 \\
\hline Tannerella forsythensis $\dagger \mathrm{JCM} 10827^{\mathrm{T}}$ & 96 & 92 & 91 & 89 \\
\hline Treponema denticola JCM 8225 & 37 & 29 & 284 & $291(281)$ \\
\hline Treponema socranskii subsp. buccale JCM $8155^{\mathrm{T}}$ & 37 & 29 & 124 & 123 \\
\hline Treponema socranskii subsp. socranskii JCM $8157^{\mathrm{T}}$ & 37 & 29 & 124 & 123 \\
\hline Treponema vincentii JCM 8227 & 37 & 29 & 289 & $296(288)$ \\
\hline
\end{tabular}

* Parentheses indicate the T-RF length observed by using only size standard GS 500 ROX.

$\dagger$ Tannerella forsythensis is the new name for Bacteroides forsythus (Sakamoto et al., 2002). 
aliquot of saliva sample was diluted with buffer $(10 \mathrm{mM}$ Tris/ $\mathrm{HCl}$ and 50 $\mathrm{mM}$ EDTA, $\mathrm{pH} 8.0)$ in a $1: 2$ ratio $(\mathrm{v} / \mathrm{v})$, and washed with the same buffer. The bacterial cell pellet obtained was then resuspended in $0.5 \mathrm{ml}$ of the same buffer containing lysozyme (final concentration of $5 \mathrm{mg}$ $\mathrm{ml}^{-1}$ ) and $N$-acetylmuramidase (final concentration of $1 \mathrm{mg} \mathrm{m}^{-1}$ ). After incubation at $37^{\circ} \mathrm{C}$ for $1 \mathrm{~h}$, proteinase $\mathrm{K}$ and SDS were added to a final concentration of $2 \mathrm{mg} \mathrm{ml}^{-1}$ and $1 \%(\mathrm{w} / \mathrm{v})$, respectively. The mixture was incubated at $50{ }^{\circ} \mathrm{C}$ for $2 \mathrm{~h}$. Nucleic acids were released by three cycles of freezing in a $-80^{\circ} \mathrm{C}$ freezer followed by thawing in a $65^{\circ} \mathrm{C}$ water bath. The mixture was then extracted with equal volumes of phenol (saturated with $10 \mathrm{mM}$ Tris/ $\mathrm{HCl}, \mathrm{pH} 8.0$ ) and phenol/chloroform-isoamyl alcohol $(25: 24: 1)$. Bulk nucleic acids were precipitated from solution with isopropyl alcohol followed by centrifugation. The DNA precipitate was washed with $70 \%$ ethanol and resuspended in $100 \mu \mathrm{TE}(10 \mathrm{mM}$ Tris/HCl and $1 \mathrm{mM}$ EDTA, pH 8.0). RNase was added to a final concentration of $10 \mu \mathrm{g} \mathrm{ml}^{-1}$, and the mixture was incubated at $37^{\circ} \mathrm{C}$ for $1 \mathrm{~h}$. The DNA was precipitated again with isopropyl alcohol. The DNA was pelleted by centrifugation, washed with $70 \%$ ethanol, dried in vacuum for $10 \mathrm{~min}$, and dissolved in $100 \mu \mathrm{l}$ of TE buffer.

PCR amplification of $\mathbf{1 6 S}$ rDNA. The primers used for the PCR amplification of $16 \mathrm{~S}$ rDNA sequences were 27F (5'-AGAGTTT GATCCTGGCTCAG-3') and 1492R (5'-GGTTACCTTGTTACG ACTT-3') (Lane, 1991) or the Spirochaeta-selective reverse primer (5'-GTTACGACTTCACCCTCCT-3') (Paster et al., 2001; Dewhirst et al., 2000). 27F was labelled at the $5^{\prime}$ end with the $6^{\prime}$-carboxyfluorescein (6-FAM), which was synthesized by Applied Biosystems Japan. Amplification reactions were performed in a total volume of $50 \mu \mathrm{l}$ containing $5 \mu \mathrm{l}$ dissolved DNA (100 ng), 1.25 U TaKaRa Ex Taq (Takara Shuzo), $5 \mu \mathrm{l} 10 \times$ Ex Taq buffer, $4 \mu \mathrm{l}$ dNTP mixture $(2.5 \mathrm{mM}$ each $)$ and $10 \mathrm{pmol}$ each primer. $16 \mathrm{~S}$ rDNAs were amplified in a Biometra Thermocycler TGradient using the following programme: $95^{\circ} \mathrm{C}$ for $3 \mathrm{~min}$, followed by 30 cycles consisting of $95^{\circ} \mathrm{C}$ for $30 \mathrm{~s}, 50^{\circ} \mathrm{C}$ for $30 \mathrm{~s}$ and $72^{\circ} \mathrm{C}$ for $1.5 \mathrm{~min}$, with a final extension period at $72{ }^{\circ} \mathrm{C}$ for $10 \mathrm{~min}$. Spirochaeta-specific $16 \mathrm{~S}$ rDNAs were amplified using the following protocol (Paster et al., 2001; Dewhirst et al., 2000): $95^{\circ} \mathrm{C}$ for $3 \mathrm{~min}$, followed by 30 cycles consisting of $94{ }^{\circ} \mathrm{C}$ for $45 \mathrm{~s}, 60^{\circ} \mathrm{C}$ for $45 \mathrm{~s}$ and $72{ }^{\circ} \mathrm{C}$ for 1.5 min with an additional $5 \mathrm{~s}$ for each cycle, with a final extension period at $72{ }^{\circ} \mathrm{C}$ for $15 \mathrm{~min}$. Amplified DNA was verified by electrophoresis of aliquots of PCR mixtures $(2 \mu \mathrm{l})$ in $1.5 \%$ agarose in $1 \times$ TAE buffer. PCR products were purified by the PEG precipitation method (Hiraishi et al., 1995) with some modifications. A $50 \mu$ laliquot of the $16 \mathrm{~S}$ rDNA solution was mixed with $30 \mu \mathrm{l}$ of a PEG solution (40\% PEG 6000 and $10 \mathrm{mM} \mathrm{MgCl}_{2}$ ) and $12 \mu \mathrm{l} 3 \mathrm{M}$ sodium acetate, gently shaken for $10 \mathrm{~min}$ at room temperature, and centrifuged at 14000 r.p.m. for $15 \mathrm{~min}$. The supernatant was removed carefully by pipetting, and then the precipitated DNA was washed twice with $70 \%$ ethanol and redissolved in $20 \mu \mathrm{l}$ sterile distilled water. Purified $16 \mathrm{~S}$ rDNAs were stored at $-20^{\circ} \mathrm{C}$ until analysis.

T-RFLP analysis. The restriction enzymes were selected according to Moyer et al. (1996). Purified PCR product $(2 \mu \mathrm{l})$ was digested with $20 \mathrm{U}$ of either HhaI or MspI (Takara Shuzo) in a total volume of $10 \mu \mathrm{l}$ at $37^{\circ} \mathrm{C}$ for $3 \mathrm{~h}$. Preliminary experiments conducted at various digestion times (3, 6 and $12 \mathrm{~h})$ and enzyme concentrations (10, 20 and $30 \mathrm{U})$ demonstrated that $3 \mathrm{~h}$ and $20 \mathrm{U}$ were sufficient for complete digestion of the PCR products. The restriction digest product $(1 \mu \mathrm{l})$ was mixed with $12 \mu \mathrm{l}$ of deionized formamide and $1 \mu \mathrm{l}$ DNA fragment-length standard. The standard size marker was a 1:1 mixture of the size standards GS 500 ROX (including 35, 50, 75, 100, 139, 150, 160, 200, $300,350,400,450,490$ and $500 \mathrm{bp}$ ) and GS 1000 ROX (including 29, 33, $37,64,67,75,81,108,118,244,275,299,421,539,674,677$ and 926 bp) (Applied Biosystems). Each sample was denatured at $95^{\circ} \mathrm{C}$ for $2 \mathrm{~min}$ and then immediately placed on ice. The length of the terminal restriction fragment (T-RF) was determined on an ABI PRISM 310 genetic analyser (Applied Biosystems) in GeneScan mode $(15 \mathrm{kV}, 8 \mathrm{~mA}$ and $60{ }^{\circ} \mathrm{C}$ for $48 \mathrm{~min}$ for each sample). Fragment sizes were estimated by using the Local Southern Method in GeneScan 3.1 software (Applied Biosystems). T-RFs with a peak height less than 25 fluorescence units were excluded from the analysis. Fragments were resolved to one base pair by manual alignment of the size standard peaks from different electropherograms as described previously (Clement et al., 1998). Predicted T-RFLP patterns of the 16S rDNAs of known bacterial species were obtained using the GENETYX-MAC program (Software Developing Co., Tokyo).

Numerical analysis. The methods developed for numerical analysis of quinone profiles (Hiraishi et al., 1991; Iwasaki \& Hiraishi, 1998) have been applied for processing T-RFLP data (Hiraishi et al., 2000). Differences in T-RFLP patterns among samples were evaluated using the dissimilarity $(D)$ index (Hiraishi et al., 1991). To evaluate the diversity of microbial communities, another parameter, the microbial divergence index based on T-RFLP patterns $\left(M D_{\mathrm{t}}\right)$, was used (Iwasaki \& Hiraishi, 1998). The $D$ and $M D_{\mathrm{t}}$ values were calculated using the BioCLUST program (Iwasaki \& Hiraishi, 1998). Dendrograms based on $D$ matrix data were constructed by the neighbour-joining method (Saitou \& Nei, 1987), and drawn using the TreeView program (Page, 1996).

\section{RESULTS AND DISCUSSION}

\section{T-RFLP analysis of a single organism}

T-RF lengths were determined for all bacteria used. The observed T-RF lengths were different (by $4 \mathrm{bp}$ ) from the predicted lengths (Table 1), with one exception: the observed T-RF lengths (29 bp) of Treponema species after digestion with HhaI were $8 \mathrm{bp}$ smaller than the predicted length (37 $\mathrm{bp})$. Although the predicted length is within the range of standards (29-926 bp), discrepancies were observed. The reason for this difference is not known. In addition, the observed T-RF lengths of Fusobacterium nucleatum, $T$. denticola and Treponema vincentii after digestion with MspI were 10,7 and $7 \mathrm{bp}$ larger than the predicted length, respectively. However, by using the only size standard GS 500 ROX, the observed T-RF lengths of F. nucleatum (283 $\mathrm{bp}), T$. denticola (281 bp) and T. vincentii (288 bp) were within $3 \mathrm{bp}$ of the predicted T-RF length. These findings emphasize the importance of selecting a suitable standard for accurate determination of the fragment size. These discrepancies between predicted and observed T-RF lengths have been reported previously (Liu et al., 1997; Clement et al., 1998; Kaplan et al., 2001; Kitts, 2001). To compensate for the differences, Kaplan et al. (2001) used a matching window that allows an observed T-RF length (from a sample) to be within +1 to -4 of the predicted T-RF length (in the database).

\section{Reproducibility}

Reproducibility of T-RFLP patterns was investigated in detail previously (Osborn et al., 2000). To assess the reproducibility of T-RFLP analysis, intragel/polymer variation (same electrophoresis gel/polymer) was investigated by three replicate electrophoresis of a sample (P17) from a patient with periodontitis generated after digestion with $\mathrm{HhaI}$ on the 
same gel/polymer. Intergel/polymer variation (different gels/ polymers) was investigated by electrophoresis of the same sample on three different gels/polymers. Seventeen T-RFs were common to all T-RFLP patterns (Table 2). Only one additional T-RF was observed in a T-RFLP pattern. Osborn et al. (2000) indicated that the greatest source of variation was the result of uneven sample loading into wells of a gel. They found that the degree of variation between replicate runs of the same sample was lower than that experienced with manual loading of acrylamide gels when they used a capillary-based electrophoresis system (ABI Prism 310) with automated sample loading, which was similar to that used in our study.

In addition, the variability generated during two stages of the T-RFLP protocol was investigated as described previously (Osborn et al., 2000): (i) variation between three different PCRs from a single DNA sample; and (ii) variation between three different digestions of the PCR product from a single PCR from a single DNA sample. Seventeen T-RFs were common to all the T-RFLP patterns as well as the results of intra- and intergel/polymer variation. These results indicate that there is the reproducibility of the data, although minor variation in peak height was observed (data not shown).

\section{Analysis of diversity of oral bacterial community by T-RFLP}

The universal primers $27 \mathrm{~F}$ and $1492 \mathrm{R}$ were used to characterize oral bacterial community. Although this primer pair may not amplify all of the $16 \mathrm{~S}$ rDNAs of organisms in saliva, and not accurately preserve the evenness of the original community DNA template, PCR amplification with primer pair $27 \mathrm{~F}-1492 \mathrm{R}$ followed by digestion with $\mathrm{Hha \textrm {I }}$ or Msp I is considered to be the simplest approach to classify the largest number of $16 \mathrm{~S}$ rRNA gene sequences into the largest number of unique T-RFs in the present study.

T-RFLP patterns with two different restriction enzymes were compared -these are available as supplementary data in JMM Online (http://jmm.sgmjournals.org). MspI generated larger numbers of T-RFs than HhaI. Each of the 36 patterns showed 5-35 T-RFs after digestion with HhaI. A total of 68 different T-RFs were detected. The size of the majority of HhaI-digested T-RFs was less than $600 \mathrm{bp}$. The major T-RFs of around $578 \mathrm{bp}$ were detected in the T-RFLP patterns of all

Table 2. Reproducibility of T-RFLP pattern

The number of common T-RFs was 17.

\begin{tabular}{|lccc|}
\hline Source of variation & \multicolumn{3}{c|}{ No. T-RFs (replicate no.) } \\
\cline { 2 - 4 } & $\mathbf{1}$ & $\mathbf{2}$ & $\mathbf{3}$ \\
\hline Intragel/polymer & 18 & 17 & 17 \\
Intergel/polymer & 18 & 17 & 17 \\
Digests & 18 & 17 & 18 \\
PCR & 18 & 17 & 17 \\
\hline
\end{tabular}

samples $(31 \cdot 8-84 \cdot 3 \%)$. The computer-simulated T-RFLP analysis showed that the T-RFs of around $578 \mathrm{bp}$ were derived from the members of the genus Streptococcus. This result is in good agreement with that of the $16 \mathrm{~S}$ rDNA clone library analysis of human saliva (Sakamoto et al., 2000), in which large numbers of clones were phylogenetically related to the genus Streptococcus (i.e. Streptococcus gordonii, Streptococcus mitis, Streptococcus parasanguinis, Streptococcus pneumoniae, Streptococcus salivarius and Streptococcus sanguinis). In addition, T-RFLP analysis of these clones (streptococci derived) confirmed the above presumption (data not shown).

A $29 \mathrm{bp}$ T-RF was identified in the T-RFLP patterns of only four samples (P1, P7, P15 and P17) from patients with periodontitis generated after digestion with HhaI (Fig. 1). According to T-RFLP analysis of a single organism (Table 1) and the computer-simulated T-RFLP analysis, it was considered that the $29 \mathrm{bp}$ T-RF was derived from oral spirochaetes. This presumption was supported by the T-RFLP patterns of the above four samples generated after digestion with MspI (data not shown). Furthermore, these four samples produced the specific PCR products for T. denticola and T. socranskii (our unpublished data). Choi et al. (1994) reported that although approximately $20 \%$ of the bacteria in a subgingival plaque sample from a single patient with destructive periodontitis were spirochaetes, treponemespecific clones represented about 7 and $1 \%$ of clones randomly selected from the DNA and cDNA libraries, respectively. This finding suggested that the proportion of treponeme-specific clones was low for 16S rRNA libraries when all-bacterial primers were used. Thus, the $29 \mathrm{bp}$ T-RF would be detected in only four samples from patients and a small population $(0 \cdot 8-3 \cdot 4 \%)$. PCR bias has been described previously (Farrelly et al., 1995; Suzuki \& Giovannoni, 1996). Liu et al. (1997) pointed out that data obtained by using TRFLPs should be cautiously interpreted. The reasons were as follows. The number of populations represented in the TRFLP pattern of any given community depends on the rank abundance of each populations. Microbial populations that are not numerically dominant are not represented, because the template DNAs from these populations represent a small fraction of the total community DNA. Hence, the species diversity of the microbial community is underestimated.

The above four samples generated T-RFs larger than $1000 \mathrm{bp}$ (Fig. 1), which was a relatively large population (12.9$26 \cdot 4 \%)$ compared with the 13 other samples $(1 \cdot 8-11 \cdot 6 \%$, those of P6, P10 and P11 were very small) from patients (except for P2 which did not generate T-RFs larger than 1000 bp). T-RFs larger than $1000 \mathrm{bp}$ were detected in T-RFLP patterns of samples from patients with periodontitis rather than periodontally healthy subjects. However, in preliminary experiments with P17, since a decrease in the peak heights of T-RFs larger than $1000 \mathrm{bp}$ was observed with increases in enzyme concentration and digestion time (data not shown), those T-RFs may be composed of partially digested products. The problem of incomplete digestion by the restriction enzyme has been reported in detail by Osborn et al. (2000). 
Terminal restriction fragment length (bp)

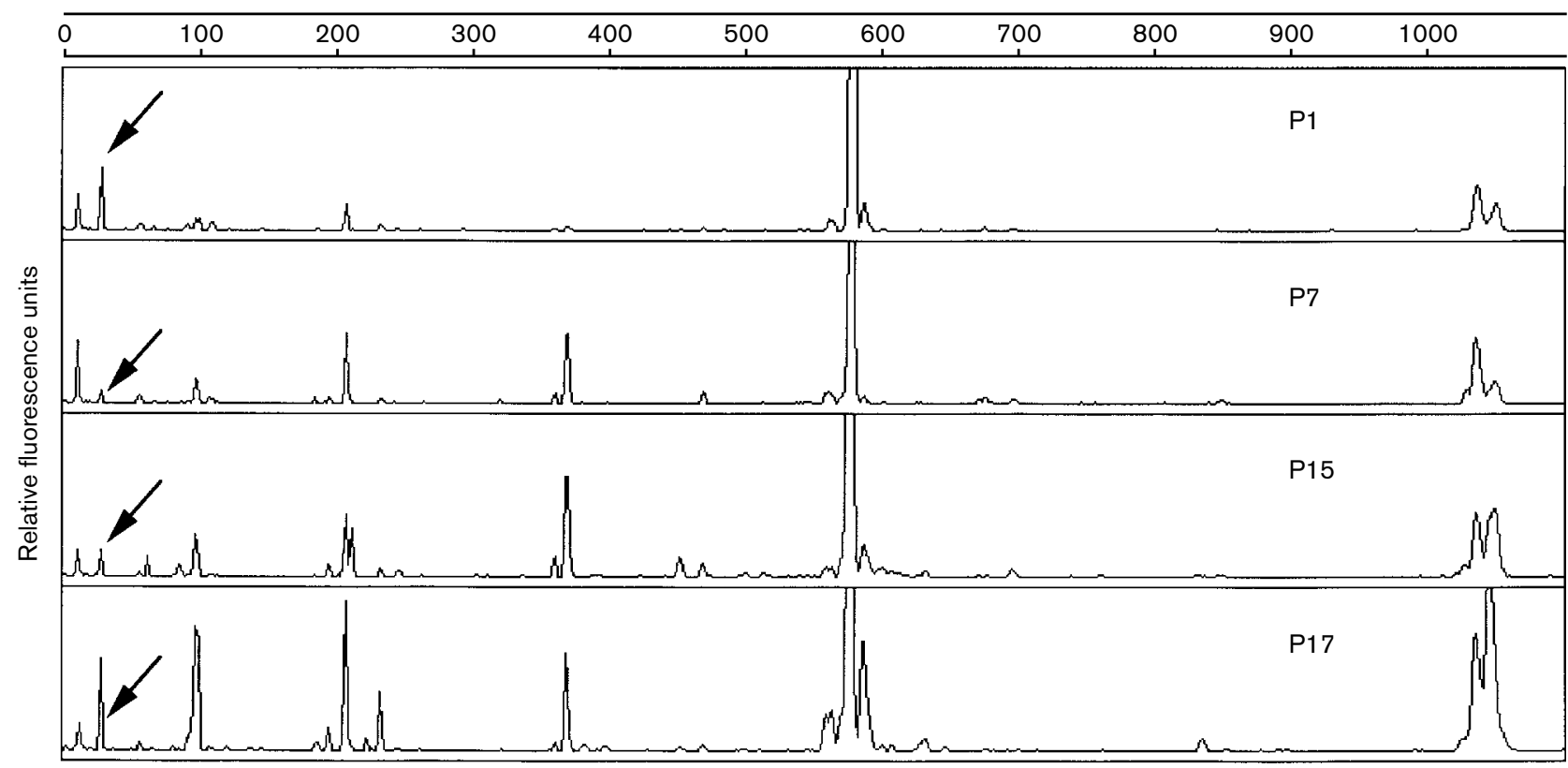

Fig. 1. T-RFLP patterns of $16 \mathrm{~S}$ rDNAs from saliva digested with Hhal. $16 \mathrm{~S}$ rDNAs were amplified with universal primers $27 \mathrm{~F}$ and $1492 \mathrm{R}$. Arrows indicate a 29 bp T-RF. Samples: $(P)$ patient with periodontitis. The minimum and maximum values of the ordinate of each T-RFLP pattern are 0 and 700 fluorescence units, respectively.

They mentioned the risk of removing genuine T-RFs that represent different members of the same genus or group when such fragments (partially digested products) are excluded from the analysis, and suggested that such fragments should be retained in the analysis.

Each of the 36 patterns showed 13-40 T-RFs after digestion with MspI. A total of 107 different T-RFs were detected. The size of the majority of MspI-digested T-RFs was less than $600 \mathrm{bp}$. The major T-RFs of around $554 \mathrm{bp}$, presumed to be members of the genus Streptococcus, were detected in T-RFLP patterns of all samples $(38 \cdot 6-85 \cdot 1 \%)$ (see supplementary data in JMM Online; http://jmm.sgmjournals.org). This result is in good agreement with that of T-RFLP patterns generated after digestion with HhaI.

\section{Analysis of diversity of spirochaetal community by T-RFLP}

Bernhard \& Field (2000) reported the T-RFLP method using the Bacteroides-Prevotella group-specific primers. In our study, we used a Spirochaeta-selective primer (Paster et al., 2001; Dewhirst et al., 2000) to characterize the community profiles of oral spirochaetes, although there is a risk that the sequence of this primer is the same as all members of the family Coriobacteriaceae (Dewhirst et al., 2001). The problem concerning the specificity of the Spirochaeta-selective primer has been discussed by Dewhirst et al. (2001). No amplicons were obtained from two samples ( $\mathrm{H} 2$ and $\mathrm{H} 5)$ of periodontally healthy subjects with $27 \mathrm{~F}$ and the Spirochaetaselective reverse primer. In addition, these two samples did not produce specific PCR products for T. denticola and $T$. socranskii (our unpublished data). Each of the 34 patterns showed 2-16 T-RFs after digestion with HhaI. A total of 43 different T-RFs were detected. The majority of HhaI-digested T-RFs were 29 and 31 bp long - see supplementary data in JMM Online (http://jmm.sgmjournals.org). The proportion of the $29 \mathrm{bp} \mathrm{T-RF}$, which is presumed to be oral spirochaetes based on T-RFLP analysis of a single organism, ranged from 21.6 to $78.5 \%(49 \cdot 2 \pm 14.9)$ (Table 3$)$. On the other hand, that of the $31 \mathrm{bp}$ T-RF was unexpectedly $1 \cdot 4-77 \cdot 3 \%$ (29.7 \pm $21 \cdot 6)$. The proportion of $31 \mathrm{bp}$ T-RFs in T-RFLP patterns of samples from periodontally healthy subjects $(43 \cdot 1 \pm 19 \cdot 7 \%)$ was larger than that in T-RFLP patterns of samples from patients with periodontitis $(17 \cdot 1 \pm 14.5 \%, P<0.001, t$ test). The $31 \mathrm{bp}$ T-RFs are probably not derived from oral spirochaetes, and further studies are necessary to verify this hypothesis. The proportion of 202 and $203 \mathrm{bp} \mathrm{T-RFs} \mathrm{in} \mathrm{the}$ T-RFLP pattern of P2 was unexpectedly $56.9 \%$ (figure in supplementary data and Table 3), although that of the $29 \mathrm{bp}$ $\mathrm{T}$-RF was small (21.6\%). In addition, the proportion of T-RF larger than $1000 \mathrm{bp}$ in T-RFLP patterns of P17 was relatively larger than that of other samples $(27.6 \%)$. The $16 \mathrm{~S}$ rDNA clone library analysis revealed that at present, there are about 60 oral treponemal species or phylotypes in human subgingival plaque (Paster et al., 2001; Dewhirst et al., 2000). Other as-yet-unidentified species or phylotypes are probably still present in the human oral cavity.

Each of the 34 patterns showed 8-33 T-RFs after digestion with MspI. A total of 92 different T-RFs were detected. The 
Table 3. Percentage of T-RFs of spirochaetal 16S rDNAs from saliva after digestion with Hhal and $\mathrm{Mspl}$

\begin{tabular}{|c|c|c|c|c|c|c|c|}
\hline \multirow[t]{2}{*}{ Subject* } & \multicolumn{4}{|c|}{ HhaI } & \multicolumn{3}{|c|}{ MspI } \\
\hline & $29 \mathrm{bp}$ & $31 \mathrm{bp}$ & $202 \mathrm{bp}$ & $203 \mathrm{bp}$ & $202 \mathrm{bp}$ & $291 \mathrm{bp}$ & $296 \mathrm{bp}$ \\
\hline $\mathrm{H} 1$ & $32 \cdot 8$ & $67 \cdot 2$ & 0 & 0 & $65 \cdot 2$ & 0 & $8 \cdot 8$ \\
\hline $\mathrm{H} 3$ & $44 \cdot 7$ & $41 \cdot 6$ & 0 & 0 & $47 \cdot 1$ & $5 \cdot 4$ & $11 \cdot 4$ \\
\hline $\mathrm{H} 4$ & $34 \cdot 1$ & $49 \cdot 5$ & 0 & 0 & $58 \cdot 7$ & $2 \cdot 1$ & $9 \cdot 5$ \\
\hline H6 & $38 \cdot 5$ & $48 \cdot 8$ & 0 & 0 & $70 \cdot 2$ & 0 & $2 \cdot 9$ \\
\hline H7 & $50 \cdot 4$ & $10 \cdot 0$ & 0 & 0 & $4 \cdot 6$ & $9 \cdot 4$ & $15 \cdot 3$ \\
\hline $\mathrm{H} 8$ & $70 \cdot 9$ & $21 \cdot 8$ & $1 \cdot 2$ & 0 & $15 \cdot 0$ & $0 \cdot 6$ & $21 \cdot 0$ \\
\hline $\mathrm{H} 9$ & $29 \cdot 9$ & $67 \cdot 8$ & 0 & 0 & $75 \cdot 4$ & 0 & $1 \cdot 0$ \\
\hline $\mathrm{H} 10$ & 41.9 & $28 \cdot 9$ & 0 & 0 & $31 \cdot 5$ & $1 \cdot 2$ & $18 \cdot 5$ \\
\hline H11 & $22 \cdot 7$ & $77 \cdot 3$ & 0 & 0 & $73 \cdot 2$ & 0 & 0 \\
\hline $\mathrm{H} 12$ & 41.9 & $42 \cdot 5$ & 0 & 0 & $57 \cdot 3$ & $1 \cdot 1$ & $15 \cdot 1$ \\
\hline H13 & $36 \cdot 9$ & $37 \cdot 3$ & 0 & 0 & $68 \cdot 0$ & $1 \cdot 9$ & $9 \cdot 0$ \\
\hline $\mathrm{H} 14$ & $37 \cdot 2$ & $59 \cdot 9$ & 0 & 0 & $51 \cdot 6$ & 0 & $1 \cdot 8$ \\
\hline H15 & $47 \cdot 5$ & $46 \cdot 8$ & 0 & 0 & $58 \cdot 3$ & $1 \cdot 3$ & $13 \cdot 6$ \\
\hline H16 & $58 \cdot 1$ & $31 \cdot 8$ & $1 \cdot 5$ & $2 \cdot 6$ & $18 \cdot 3$ & $7 \cdot 9$ & $14 \cdot 4$ \\
\hline H17 & $47 \cdot 6$ & $14 \cdot 8$ & 0 & 0 & $7 \cdot 9$ & $2 \cdot 0$ & $34 \cdot 5$ \\
\hline H18 & $39 \cdot 2$ & $57 \cdot 2$ & 0 & 0 & $77 \cdot 6$ & $0 \cdot 8$ & $4 \cdot 5$ \\
\hline P1 & $73 \cdot 3$ & $5 \cdot 1$ & $3 \cdot 0$ & 0 & $1 \cdot 1$ & $34 \cdot 6$ & $30 \cdot 4$ \\
\hline $\mathrm{P} 2$ & $21 \cdot 6$ & $1 \cdot 4$ & $36 \cdot 1$ & $20 \cdot 8$ & 0 & $7 \cdot 9$ & $3 \cdot 8$ \\
\hline P3 & $46 \cdot 0$ & 32.6 & $3 \cdot 2$ & 0 & $40 \cdot 2$ & $9 \cdot 9$ & $18 \cdot 9$ \\
\hline P4 & $45 \cdot 5$ & $19 \cdot 2$ & $6 \cdot 6$ & $3 \cdot 1$ & $30 \cdot 0$ & $20 \cdot 6$ & $6 \cdot 9$ \\
\hline P5 & $55 \cdot 0$ & $26 \cdot 6$ & $1 \cdot 1$ & $1 \cdot 1$ & $27 \cdot 1$ & $13 \cdot 5$ & $20 \cdot 6$ \\
\hline P6 & $72 \cdot 4$ & $27 \cdot 6$ & 0 & 0 & $11 \cdot 3$ & $12 \cdot 7$ & $36 \cdot 4$ \\
\hline P7 & $55 \cdot 1$ & 1.9 & 1.9 & $3 \cdot 0$ & 0 & $29 \cdot 1$ & $38 \cdot 3$ \\
\hline P8 & 39.9 & 39.4 & 0 & 0 & $20 \cdot 1$ & 0 & $5 \cdot 1$ \\
\hline P9 & $58 \cdot 4$ & 3.5 & $6 \cdot 8$ & $6 \cdot 2$ & 0 & $21 \cdot 5$ & $30 \cdot 6$ \\
\hline P10 & $48 \cdot 3$ & $36 \cdot 0$ & 0 & 0 & $27 \cdot 9$ & $2 \cdot 1$ & $13 \cdot 1$ \\
\hline P11 & 78.5 & $5 \cdot 3$ & $1 \cdot 3$ & 0 & $2 \cdot 9$ & 0 & $63 \cdot 6$ \\
\hline P12 & $55 \cdot 5$ & 5.9 & $3 \cdot 0$ & $1 \cdot 7$ & $1 \cdot 5$ & $18 \cdot 7$ & 32.5 \\
\hline P13 & $43 \cdot 6$ & $43 \cdot 6$ & 0 & 0 & $51 \cdot 9$ & $9 \cdot 1$ & $5 \cdot 3$ \\
\hline P14 & $76 \cdot 6$ & $9 \cdot 0$ & $2 \cdot 6$ & $2 \cdot 9$ & $8 \cdot 4$ & $26 \cdot 5$ & $29 \cdot 9$ \\
\hline P15 & $72 \cdot 6$ & $3 \cdot 4$ & 0 & $0 \cdot 7$ & 0 & $28 \cdot 3$ & $40 \cdot 0$ \\
\hline P16 & $54 \cdot 2$ & 13.9 & $2 \cdot 2$ & $3 \cdot 8$ & $8 \cdot 1$ & $26 \cdot 4$ & $12 \cdot 7$ \\
\hline P17 & $42 \cdot 3$ & $5 \cdot 5$ & 3.9 & $2 \cdot 6$ & $0 \cdot 4$ & $10 \cdot 0$ & $47 \cdot 9$ \\
\hline P18 & $59 \cdot 9$ & $27 \cdot 6$ & $1 \cdot 0$ & 0 & $26 \cdot 2$ & $13 \cdot 5$ & $25 \cdot 5$ \\
\hline
\end{tabular}

* $(\mathrm{H})$ periodontally healthy subject, $(\mathrm{P})$ patient with periodontitis.

size of the majority of MspI-digested T-RFs was less than 600 bp (see supplementary data in JMM Online; http:// jmm.sgmjournals.org). In T-RFLP patterns of samples from periodontally healthy subjects, T-RFs of around 202 bp were predominant (figure in supplementary data and Table 3). On the other hand, T-RFs of 202 bp plus approximately 291 and $296 \mathrm{bp}$ were predominant in T-RFLP patterns of samples from patients with periodontitis. Using a $16 \mathrm{~S}$ rRNA universal forward primer and a Spirochaeta-selective primer, Dewhirst et al. (2001) reported that $75 \%$ of the clones obtained were Treponema species, and the majority of non-spirochaete clones were closely related to the genus Atopobium in the family Coriobacteriaceae. The predicted T-RF lengths of
Atopobium species after digestion with HhaI were $37 \mathrm{bp}$, which were identical to those of spirochaetes. However, the predicted T-RF lengths of Atopobium species after digestion with MspI were different from those of spirochaetes. Consequently, the majority of $16 \mathrm{~S}$ rDNAs amplified from samples of periodontally healthy subjects may be closely related to the genus Atopobium but not spirochaetes. Further studies are necessary.

\section{Numerical analysis}

In the analysis of diversity of oral bacterial community, the number of T-RFs in patients with periodontitis (MspI: 
$27 \cdot 9 \pm 5 \cdot 8)$ was relatively larger than in periodontally healthy subjects (MspI: $22 \cdot 3 \pm 5 \cdot 6)(P<0 \cdot 05, t$-test). Although the number of HhaI-digested T-RFs in patients with periodontitis $(17 \cdot 1 \pm 7 \cdot 4)$ was slightly larger than in periodontally healthy subjects $(14 \cdot 4 \pm 5 \cdot 7)$, the difference was not statistically significant $(P>0 \cdot 05, t$-test). In addition, in the analysis of diversity of spirochaetal community, the number of T-RFs in patients with periodontitis (HhaI: $10 \cdot 1 \pm 3 \cdot 7$ and MspI: $22 \cdot 4 \pm 5 \cdot 7$ ) was larger than in periodontally healthy subjects (HhaI: $6.3 \pm 3.7$ and MspI: $15.9 \pm 5.9)(P<0.01, t$-test). Dewhirst et al. (2000) reported that the species diversity of spirochaetes in subgingival plaque was greatest in patients with acute necrotizing ulcerative gingivitis and periodontitis and least in periodontally healthy and patients with HIVperiodontitis. Our results support their report.

Dendrograms were constructed by the neighbour-joining method based on the $D$ matrix data calculated by the combination of two T-RFLP patterns with two different restriction enzymes (Figs 2 and 3). Based on the analysis of the oral bacterial community, samples from periodontally healthy and patients with periodontitis were grouped into different clusters, though with some uncertainty (Fig. 2).

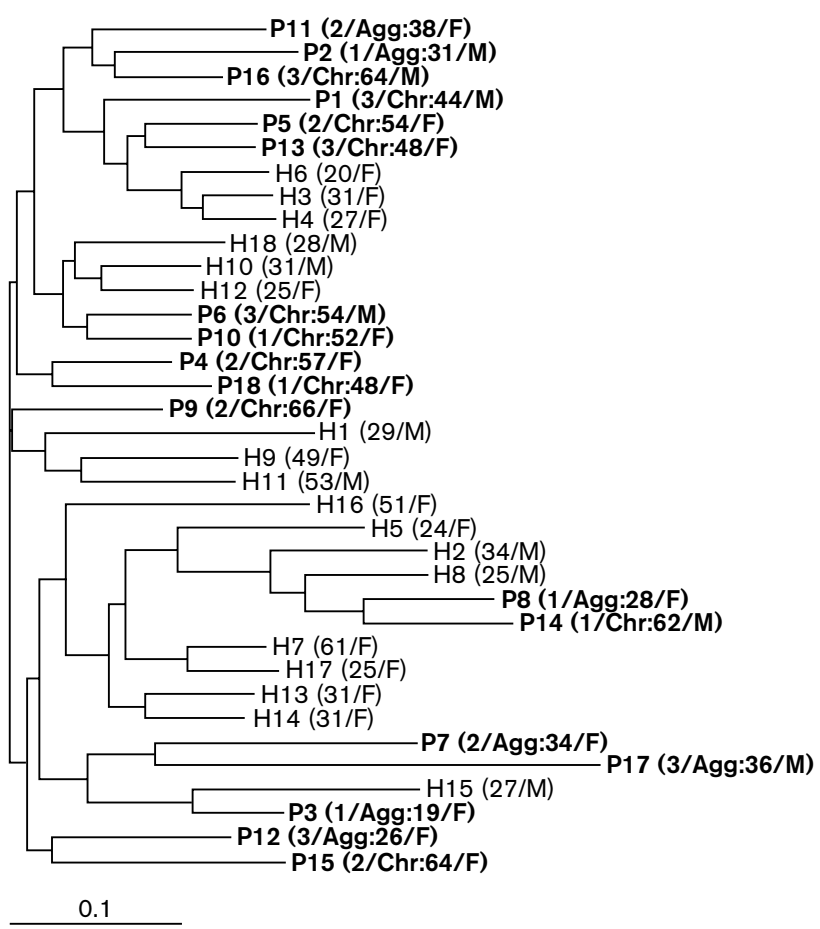

Fig. 2. Dendrogram of oral bacterial community showing the relationships among T-RFLP patterns of saliva based on $D$ matrix data calculated by the combination of two T-RFLP patterns with two different restriction enzymes (Hhal and $\mathrm{Mspl}$ ). The scale bar indicates $10 \%$ dissimilarity. Samples: $(H)$ periodontally healthy subjects and $(P)$ patients with periodontitis. Data presented in Figs 2 and 3 include group (1, group 1; 2, group 2; 3, group 3), type (Agg, aggressive periodontitis; Chr, chronic periodontitis), age and sex (F, female; $M$, male).

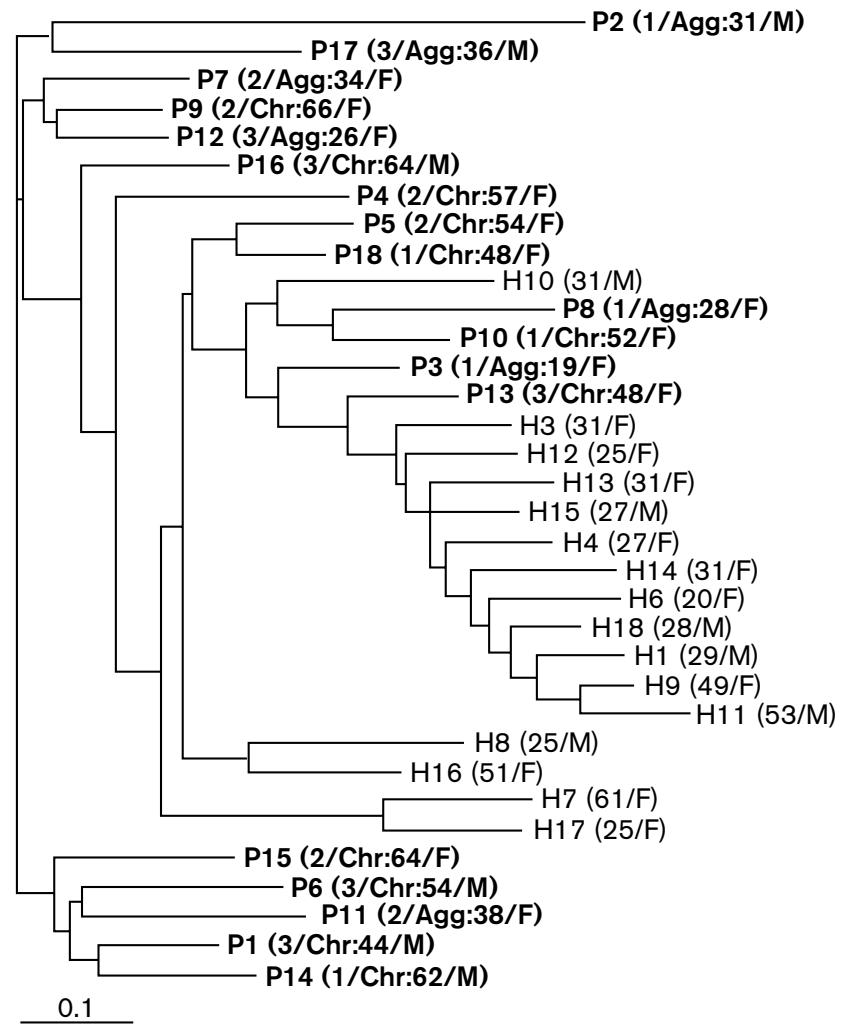

Fig. 3. Dendrogram of spirochaetal community showing the relationships among T-RFLP patterns of saliva based on $D$ matrix data calculated by the combination of two T-RFLP patterns with two different restriction enzymes (Hhal and $\mathrm{Mspl}$ ). The scale bar indicates $10 \%$ dissimilarity. Samples: $(H)$ periodontally healthy subjects and $(P)$ patients with periodontitis.

Samples from patients with periodontitis tended to cluster with their respective types (aggressive and chronic periodontitis), although this was not very clear. Interestingly, P8 and P14, which are in the maintenance stage, formed a cluster with the samples from periodontally healthy subject and were relatively separate from the samples of other patients. P8 did not produce specific PCR products for A. actinomycetemcomitans, T. forsythensis, $P$. gingivalis, $T$. denticola or $T$. socranskii, and P14 did not produce specific PCR products for A. actinomycetemcomitans or T. denticola (our unpublished data). $M D_{\mathrm{t}}$ values ranged from $4 \cdot 3$ to $20 \cdot 6$. In the analysis of the spirochaetal community (Fig. 3), the patterns derived from patients with periodontitis showed a better grouping compared with the analysis of oral bacterial community. These results suggest that samples from patients with periodontitis contain an unexpected diversity. $M D_{\mathrm{t}}$ values ranged from $3 \cdot 5$ to $13 \cdot 0$.

\section{Computer-simulated T-RFLP analysis}

Spirochaetes exist in several environments (Choi et al., 1997; Iida et al., 2000; Lilburn et al., 1999; Paster et al., 1996) in addition to the human oral cavity. Furthermore, a number of 


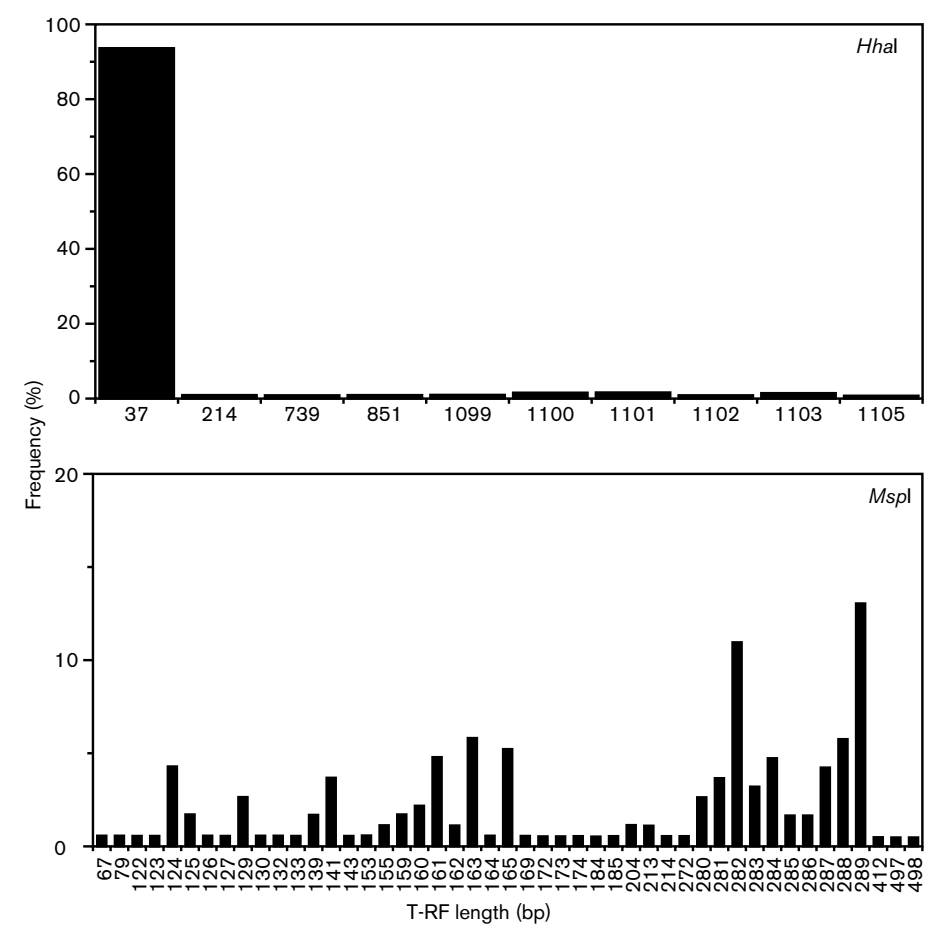

Fig. 4. Computer-simulated analysis of T-RFs in the genus Treponema. The 194 sequences were selected for analysis.

spirochaetes are present in termite guts (Lilburn et al., 1999). The 16S rDNA clone library analysis revealed that all termitegut spirochaetal clones were affiliated with the genus Treponema (Iida et al., 2000; Lilburn et al., 1999; Paster et al., 1996). Lilburn et al. (1999) reported that at least 21 new species of Treponema were recognized within one termite species. In our study, 194 treponemal sequences (including termite-gut spirochaetal clones) retrieved from the DDBJ/ EMBL/GenBank were selected for the T-RFLP analysis. The size distribution of T-RFs predicted for treponemes is shown in Fig. 4. The number of T-RFs after digestion with MspI was larger than that after digestion with HhaI. These results are in agreement with the analysis of diversity of the spirochaetal community. From the computer-simulated T-RFLP analysis with $\mathrm{HhaI}$, although the proportion of the $37 \mathrm{bp}$ T-RF, which corresponds to the $29 \mathrm{bp} \mathrm{T-RF}$ observed in this study, was about $90 \%$, that of the $29 \mathrm{bp}$ T-RF ranged from 21.6 to $78.5 \%$. Unexpectedly, the proportion of the 31 bp T-RF was large $(1 \cdot 4-77 \cdot 3 \%)$. Furthermore, T-RFs of around $202 \mathrm{bp}$ plus approximately 291 and $296 \mathrm{bp}$ (from oral spirochaetes) were predominant in the analysis with MspI. In the computer-simulated T-RFLP analysis, the proportion of T-RFs of around $202 \mathrm{bp}$ was not large. These findings indicate that the 31 bp T-RF (with HhaI) and T-RFs of around $202 \mathrm{bp}$ (with $M s p I)$ are probably not derived from oral spirochaetes. In the future, we will design and use a more specific primer for oral spirochaetes.

\section{Host-specific and stable T-RFLP patterns of oral bacterial community in human saliva}

Finally, we also investigated the stability of the oral bacterial community over a 5-week period (Fig. 5). Although a minor change in T-RFLP pattern was observed, saliva samples from the same subject produced similar T-RFLP patterns irrespective of the sampling time. These results suggested that the change in oral bacterial flora was relatively small in daily life and demonstrates the usefulness of this method for monitoring the oral bacterial flora of an individual over a period of time.

\section{Conclusion}

Although the subject population was small, our study demonstrated that T-RFLP analysis is useful for assessment of the diversity of the oral bacterial flora and rapid comparison of the community structure among individuals with and without periodontitis. The approach reported here should be useful in the future to elucidate the aetiology of periodontal disease and to develop new diagnostic tools, disease-prevention programmes and treatment modalities. Studies are under way in our laboratories to examine the effects of medical treatment of periodontitis on T-RFLP patterns.

\section{ACKNOWLEDGEMENTS}

We thank Dr Akira Hiraishi (Department of Ecological Engineering, Toyohashi University of Technology) for providing the BioCLUST program and Dr Bruce J. Paster (Department of Molecular Genetics, The Forsyth Institute) for critical reading of the manuscript. This work was supported in part by a Grant-in-Aid for Scientific Research (no. 13672202) from the Japan Society for the Promotion of Science (to M. S.). 
Terminal restriction fragment length (bp)

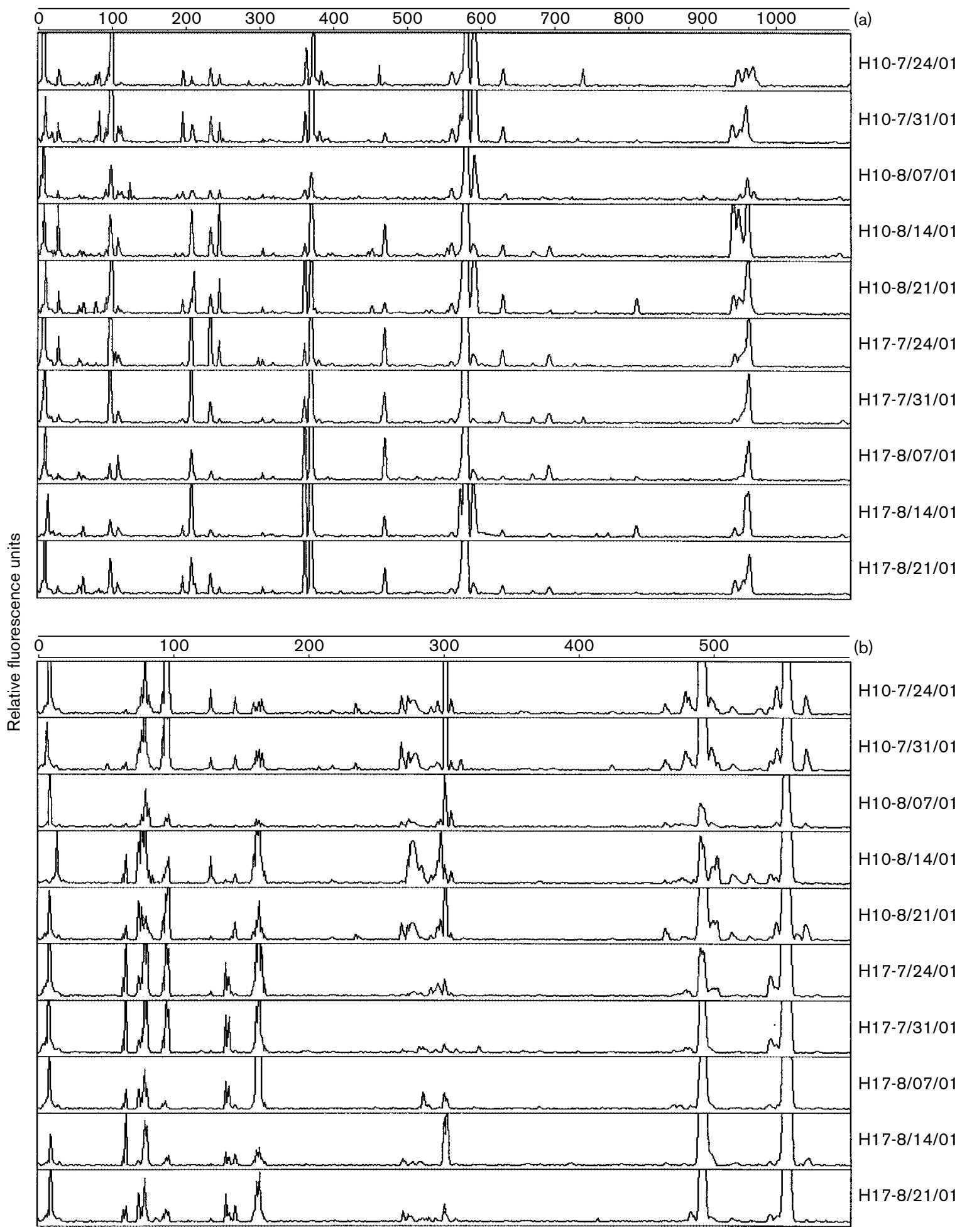

Fig. 5. T-RFLP patterns of $16 \mathrm{~S}$ rDNAs from saliva samples of two periodontally healthy subjects $(\mathrm{H} 10$ and $\mathrm{H} 17)$ from a 5 -week period (24 July 2001, 31 July 2001, 7 August 2001, 14 August 2001 and 21 August 2001) generated after digestion with Hhal (a) and Mspl (b). 16S rDNAs were amplified with universal primers 27F and 1492R. The minimum and maximum values of the ordinate of each T-RFLP pattern are 0 and 300 fluorescence units, respectively. 


\section{REFERENCES}

Bernhard, A. E. \& Field, K. G. (2000). Identification of nonpoint sources of fecal pollution in coastal waters by using host-specific $16 \mathrm{~S}$ ribosomal DNA genetic markers from fecal anaerobes. Appl Environ Microbiol 66, 1587-1594.

Choi, B. K., Paster, B. J., Dewhirst, F. E. \& Göbel, U. B. (1994). Diversity of cultivable and uncultivable oral spirochetes from a patient with severe destructive periodontitis. Infect Immun 62, 1889-1895.

Choi, B. K., Wyss, C. \& Göbel, U. B. (1996). Phylogenetic analysis of pathogen-related oral spirochetes. J Clin Microbiol 34, 1922-1925.

Choi, B. K., Nattermann, H., Grund, S., Haider, W. \& Göbel, U. B. (1997). Spirochetes from digital dermatitis lesions in cattle are closely related to treponemes associated with human periodontitis. Int J Syst Bacteriol 47, $175-181$.

Clement, B. G., Kehl, L. E., DeBord, K. L. \& Kitts, C. L. (1998). Terminal restriction fragment patterns (TRFPs), a rapid, PCR-based method for the comparison of complex bacterial communities. J Microbiol Methods 31, 135-142.

Dewhirst, F. E., Tamer, M. A., Ericson, R. E., Lau, C. N., Levanos, V. A., Boches, S. K., Galvin, J. L. \& Paster, B. J. (2000). The diversity of periodontal spirochetes by $16 \mathrm{~S}$ rRNA analysis. Oral Microbiol Immunol 15, 196-202.

Dewhirst, F. E., Paster, B. J., Tzellas, N., Coleman, B., Downes, J., Spratt, D. A. \& Wade, W. G. (2001). Characterization of novel human oral isolates and cloned 16S rDNA sequences that fall in the family Coriobacteriaceae: description of Olsenella gen. nov., reclassification of Lactobacillus uli as Olsenella uli comb. nov. and description of Olsenella profusa sp. nov. Int J Syst Evol Microbiol 51, 1797-1804.

Dunbar, J., Ticknor, L. O. \& Kuske, C. R. (2000). Assessment of microbial diversity in four southwestern United States soils by 16S rRNA gene terminal restriction fragment analysis. Appl Environ Microbiol 66, 2943-2950.

Dymock, D., Weightman, A. J., Scully, C. \& Wade, W. G. (1996). Molecular analysis of microflora associated with dentoalveolar abscesses. J Clin Microbiol 34, 537-542.

Farrelly, V., Rainey, F. A. \& Stackebrandt, E. (1995). Effect of genome size and $r r n$ gene copy number on PCR amplification of 16S rRNA genes from a mixture of bacterial species. Appl Environ Microbiol 61, $2798-2801$.

Gonzàlez, J. M., Simó, R., Massana, R., Covert, J. S., Casamayor, E. O., Pedros-Alio, C. \& Moran, M. A. (2000). Bacterial community structure associated with a dimethylsulfonipropionate-producing North Atlantic algal bloom. Appl Environ Microbiol 66, 4237-4246.

Hiraishi, A., Morishima, Y. \& Takeuchi, J. (1991). Numerical analysis of lipoquinone patterns in monitoring bacterial community dynamics in wastewater treatment systems. J Gen Appl Microbiol 37, 57-70.

Hiraishi, A., Kamagata, Y. \& Nakamura, K. (1995). Polymerase chain reaction amplification and restriction fragment length polymorphism analysis of $16 \mathrm{~S}$ rRNA genes from methanogens. J Ferment Bioeng 79, $523-529$.

Hiraishi, A., Iwasaki, M. \& Shinjo, H. (2000). Terminal restriction pattern analysis of $16 \mathrm{~S}$ rRNA genes for the characterization of bacterial communities of activated sludge. J Biosci Bioeng 90, 148-156.

lida, T., Ohkuma, M., Ohtoko, K. \& Kudo, T. (2000). Symbiotic spirochetes in the termite hindgut: phylogenetic identification of ectosymbiotic spirochetes of oxymonad protists. FEMS Microbiol Ecol $34,17-26$.

Iwasaki, M. \& Hiraishi, A. (1998). A new approach to numerical analyses of microbial quinone profiles in the environment. Microbes Environ 13, $67-76$.

Kaplan, C. W., Astaire, J. C., Sanders, M. E., Reddy, B. S. \& Kitts, C. L.
(2001). 16S ribosomal DNA terminal restriction fragment pattern analysis of bacterial communities in feces of rats fed Lactobacillus acidophilus NCFM. Appl Environ Microbiol 67, 1935-1939.

Kitts, C. L. (2001). Terminal restriction fragment patterns: a tool for comparing microbial communities and assessing community dynamics. Curr Issues Intest Microbiol 2, 17-25.

Kroes, I., Lepp, P. W. \& Relman, D. A. (1999). Bacterial diversity within the human subgingival crevice. Proc Natl Acad Sci U S A 96, 1454714552.

Lane, D. J. (1991). 16S/23S rRNA sequencing. In Nucleic Acid Techniques in Bacterial Systematics, pp. 115-175. Edited by E. Stackebrandt \& M. Goodfellow. Chichester: Wiley.

Leser, T. D., Lindecrona, R. H., Jensen, T. K., Jensen, B. B. \& Møller, K. (2000). Changes in bacterial community structure in the colon of pigs fed different experimental diets and after infection with Brachyspira hyodysenteriae. Appl Environ Microbiol 66, 3290-3296.

Lilburn, T. G., Schmidt, T. M. \& Breznak, J. A. (1999). Phylogenetic diversity of termite gut spirochaetes. Environ Microbiol 1, 331-345.

Liu, W.-T., Marsh, T. L., Cheng, H. \& Forney, L. J. (1997). Characterization of microbial diversity by determining terminal restriction fragment length polymorphisms of genes encoding 16S rRNA. Appl Environ Microbiol 63, 4516-4522.

Lukow, T., Dunfield, P. F. \& Liesack, W. (2000). Use of the T-RFLP technique to assess spatial and temporal changes in the bacterial community structure within an agricultural soil planted with transgenic and non-transgenic potato plants. FEMS Microbiol Ecol 32, 241-247.

Marsh, T. L. (1999). Terminal restriction fragment length polymorphism (T-RFLP): an emerging method for characterizing diversity among homologous populations of amplification products. Curr Opin Microbiol 2, 323-327.

Marsh, T. L., Saxman, P., Cole, J. \& Tiedje, J. (2000). Terminal restriction fragment length polymorphism analysis program, a webbased research tool for microbial community analysis. Appl Environ Microbiol 66, 3616-3620.

Moeseneder, M. M., Arrieta, J. M., Muyzer, G., Winter, C. \& Herndl, G. J. (1999). Optimization of terminal-restriction fragment length polymorphism analysis for complex marine bacterioplankton communities and comparison with denaturing gradient gel electrophoresis. Appl Environ Microbiol 65, 3518-3525.

Moyer, C. L., Tiedje, J. M., Dobbs, F. C. \& Karl, D. M. (1996). A computersimulated restriction fragment length polymorphism analysis of bacterial small-subunit rRNA genes: efficacy of selected tetrameric restriction enzymes for studies of microbial diversity in nature. Appl Environ Microbiol 62, 2501-2507.

Osborn, A. M., Moore, E. R. B. \& Timmis, K. N. (2000). An evaluation of terminal-restriction fragment length polymorphism (T-RFLP) analysis for the study of microbial community structure and dynamics. Environ Microbiol 2, 39-50.

Page, R. D. M. (1996). TreeView: an application to display phylogenetic trees on personal computers. Comput Appl Biosci 12, 357-358.

Paster, B. J., Dewhirst, F. E., Cooke, S. M., Fussing, V., Poulsen, L. K. \& Breznak, J. A. (1996). Phylogeny of not-yet-cultured spirochetes from termite guts. Appl Environ Microbiol 62, 347-352.

Paster, B. J., Boches, S. K., Galvin, J. L., Ericson, R. E., Lau, C. N., Levanos, V. A., Sahasrabudhe, A. \& Dewhirst, F. E. (2001). Bacterial diversity in human subgingival plaque. J Bacteriol 183, 3770-3783.

Saitou, N. \& Nei, M. (1987). The neighbor-joining method: a new method for reconstructing phylogenetic trees. Mol Biol Evol 4, 406-425.

Sakamoto, M., Takeuchi, Y., Umeda, M., Ishikawa, I., Benno, Y. \& Nakase, T. (1999). Detection of Treponema socranskii associated with human periodontitis by PCR. Microbiol Immunol 43, 485-490. 
Sakamoto, M., Umeda, M., Ishikawa, I. \& Benno, Y. (2000). Comparison of the oral bacterial flora in saliva from a healthy subject and two periodontitis patients by sequence analysis of $16 \mathrm{~S} \mathrm{rDNA}$ libraries. Microbiol Immunol 44, 643-652.

Sakamoto, M., Takeuchi, Y., Umeda, M., Ishikawa, I. \& Benno, Y. (2001). Rapid detection and quantification of five periodontopathic bacteria by real-time PCR. Microbiol Immunol 45, 39-44.

Sakamoto, M., Suzuki, M., Umeda, M., Ishikawa, I. \& Benno, Y. (2002). Reclassification of Bacteroides forsythus (Tanner et al. 1986) as Tannerella forsythensis corrig., gen. nov., comb. nov. Int J Syst Evol Microbiol 52, 841-849.
Spratt, D. A., Weightman, A. J. \& Wade, W. G. (1999). Diversity of oral asaccharolytic Eubacterium species in periodontitis-identification of novel phylotypes representing uncultivated taxa. Oral Microbiol Immunol 14, 56-59.

Suzuki, M. T. \& Giovannoni, S. J. (1996). Bias caused by template annealing in the amplification of mixtures of $16 \mathrm{~S}$ rRNA genes by PCR. Appl Environ Microbiol 62, 625-630.

Umeda, M., Contreras, A., Chen, C., Bakker, I. \& Slots, J. (1998). The utility of whole saliva to detect the oral presence of periodontopathic bacteria. J Periodontol 69, 828-833. 